\title{
Status and revision of the genus Pbilanglaus Butler, 1882 (Lepidoptera: Cossidae: Hypoptinae) from Southern Peru and Chile
}

\author{
Статус и ревизия рода Pbilanglaus Butler, 1882 (Lepidoptera: \\ Cossidae: Hypoptinae) из Южного Перу и Чили
}

\author{
R.V. Yakovlev ${ }^{1,2}$, F.C. Penco ${ }^{3}$, A.E. Naydenov ${ }^{1}$ \\ Р.В. Яковлев ${ }^{1,2}$, Ф.Ц. Пенко ${ }^{3}$, А.Е. Найдёнов ${ }^{1}$
}

\footnotetext{
${ }^{1}$ Altai State University, pr. Lenina 61, Barnaul 656049, Russia. E-mail: colias24@mail.ru; yakovlev_asu@mail.ru

2 Tomsk State University, Laboratory of Biodiversity and Ecology, Lenin pr. 36, 634050 Tomsk, Russia.

${ }^{3}$ Fundación de Historia Natural "Félix de Azara”, Departamento de Ciencias Naturales y Antropología, Universidad Maimónides, Hidalgo 775 piso 7 (1405BDB) Ciudad Autónoma de Buenos Aires, Argentina. E-mail: fernando_penco@hotmail.com

${ }^{1}$ Алтайский государственный университет, пр. Ленина 61, Барнаул 656049, Россия.

2 Томский государственный университет, пр. Ленина 36, Томск 634050, Россия.
}

KEY WORDS: Biodiversity, Carpenter moths, fauna, Patagonia, Neotropical Region, taxonomy.

КЛЮЧЕВЫЕ СЛОВА: биоразнообразие, древоточцы, фауна, Патагония, Неотропический регион, таксономия.

ABSTRACT. The article confirms the generic status of Philanglaus Butler, 1882. The genus includes two species: P. ornatus Butler, 1882 and Philanglaus xylodopoecila (Zukowsky, 1954), distributed in semidesert regions of southern Peru and Chile. The illustrated redescriptions of both species are provided. One new combination is established: Philanglaus xylodopoecila (Zukowsky, 1954) comb.n. The genus distribution map is given.

РЕЗЮМЕ. В статье подтверждается родовой статус рода Philanglaus Butler, 1882. Род включает два вида: P. ornatus Butler, 1882 и P. xylodopoecila (Zukowsky, 1954), распространённых в полупустынных регионах юга Перу и Чили. Даны иллюстрированные переописания обоих видов. Выделен неотип Langsdorfia xylodopoecila Zukowsky, 1954. Установлена новая комбинация — Philanglaus xylodopoecila (Zukowsky, 1954) comb.n. Дана карта распространения рода.

\section{Introduction}

South American Cossidae are studied very poorly, it primarily concerns the large subfamily of Hypoptinae. The revision of the subfamily started by us [Yakovlev et al., 2019; Naydenov et al., 2020] has already allowed to describe more than 30 taxa of species and generic range from various parts of the Neotropics. Examining the collections materials in the museums of Europe and
South America, we studied the type and supplementary specimens of peculiar Hypoptinae from the deserts of southern Peru and Chile, that allowed us to obtain new data on the taxonomy and distribution of the genus Philanglaus Butler, 1882, the status of which had been often changed before.

Philanglaus Butler, 1882 was described as genus in the family Hepialidae for the unique species Philanglaus ornatus Butler, 1882 from Chile [Butler, 1882]. Schaus [1905] moved the genus to Cossidae. Later, Schaus [1905, 1921] and Dognin [1910, 1923] described four species in the genus Philanglaus: P. sobrana Schaus, 1905, P. metana Dognin, 1910, P. beatrix Schaus, 1921, and P. invetita Dognin, 1923. Dyar [1940] suggested the new combinations: Langsdorfia metana, L. sobrana and L. beatrix. Ureta [1957] suggested the combination Langsdorfia ornata. Clench [1957] described Philanglaus penai Clench, 1957 from Chile. Gentili [1985] synonymized penai with ornatus and returned the generic status to the genus Philanglaus. Schoorl [1990], without examinations of genital structures, synonymized several Neotropical genera, including Philanglaus, with Hypopta Hübner, 1818. Donahue [1995] accepted the synonymy suggested by Schoorl [1990] and gave the following combinations: Hypopta ornata (= penai), H. xylodopoecila, H. metana, Langsdorfia sobrana, L. watsoni Schaus, 1901 (= invetita), and Inguromorpha beatrix. Later, the combination Dogninia beatrix (Schaus, 1921) [Yakovlev et al., 2019] was suggested.

How to cite this article: Yakovlev R.V., Penco F.C., Naydenov A.E. 2020. Status and revision of the genus Philanglaus Butler, 1882 (Lepidoptera: Cossidae: Hypoptinae) from Southern Peru and Chile// Russian Entomol. J. Vol.29. No.4. P.428-431. doi: 10.15298/rusentj.29.4.11 
Basing on the study of the type specimens male genitalia and a large amount of supplementary materials, the status of two genera, Dolecta Herrich-Schäffer, 1854 and Breyeriana Orfila, 1957 was restored by us [Penco et al., 2019; Naydenov et al., 2020]. Examining the type specimens of Philanglaus ornatus Butler, 1882 we reconstructed its generic status too. The status and generic affiliation of other species, mentioned in the Introduction, needs a further study.

\section{Material and methods}

Male genitalia were mounted in euparal on slides following Lafontaine [2004] examined with an Olympus SZX16 microscope. The images were taken with the Olympus SZX16 camera. Images of imago were taken by the digital camera of Apple iPhone 7, illuminated in Lightbox. The images were processed using CorelDraw software.

Abbreviations list: ANIC - Australian National Insect Collection, Division of Entomology, CSIRO (Canberra, Australia); CMNH - Carnegie Museum of Natural History (Pittsburg, USA); IPCN — Instituto Pat- agónico de Ciencias Naturales, San Martin de los Andes (Neuquén, Argentina); MNHC — Museo Nacional de Historia Natural (Santiago, Chile); MNKB — Museum für Naturkunde, Leibniz Institut für Evolution und Biodiversitatsforschung (Berlin, Germany); MWM - Museum Witt (Munich, Germany); MZUC - Museo de Zoologia de la Universidad de Concepción (Concepción, Chile); NHMUK - The Natural History Museum of United Kingdom (London, U.K.).

\section{Taxonomic part}

\section{Philanglaus Butler, 1882}

Type species (by monotypy) Philanglaus ornatus Butler, 1882 REDESCRIPTION. Size medium (length of fore wing 17-21 mm). Antenna bipectinate; in males - crest processes three times longer than antenna rod diameter, in females 1.5 times longer than antenna rod diameter. Wings lightbrown from above, fore wing with contrast pattern of bright brown undulated bands and spots. Hind wing light-brown with poorly expressed pattern.

Male genitalia (Figs 6-7). Uncus long, robust; gnathos arms ribbon-like, short, not fused; gnathos reduced; valve short, apically semicircular; costal edge basally with long
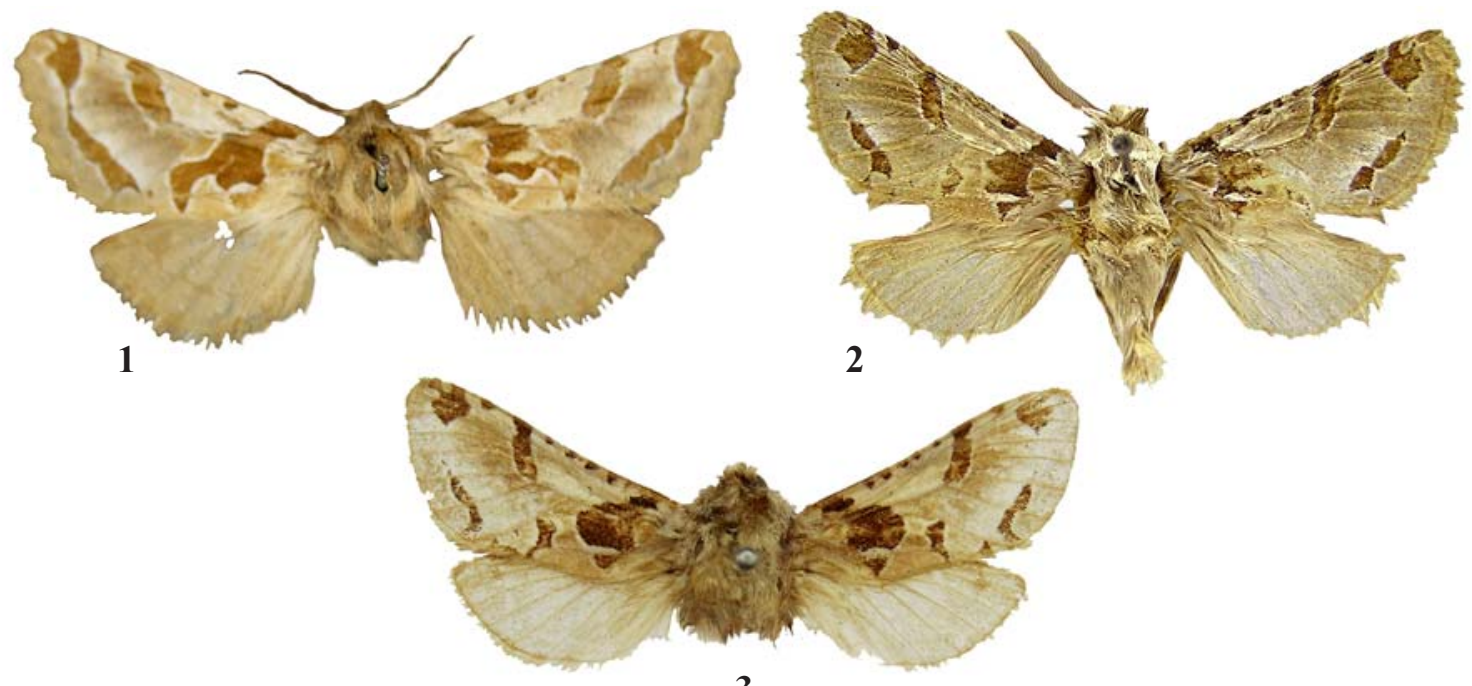

3
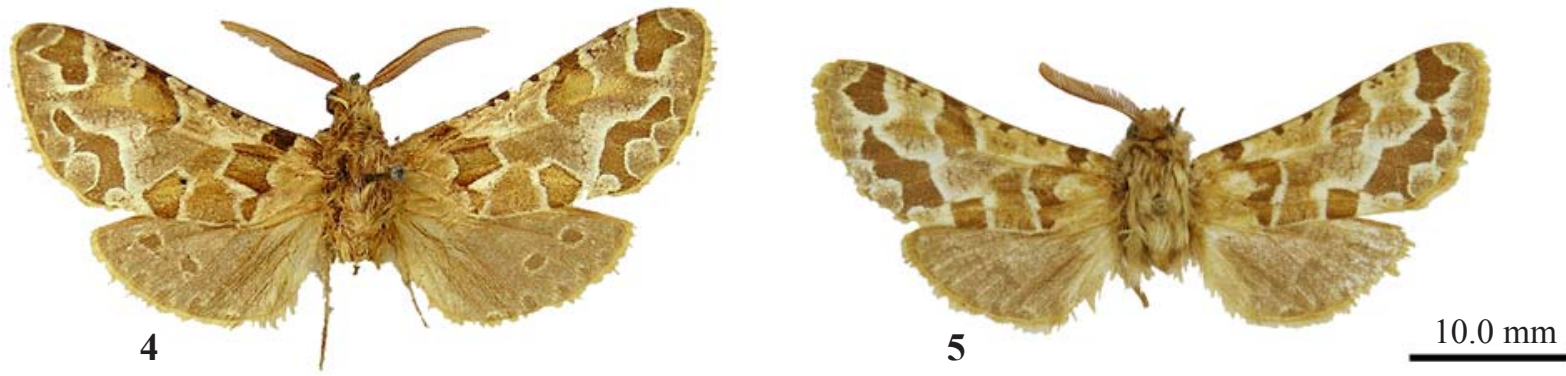

Figs 1-5. Adult specimens of Philanglaus: $1-P$. ornatus (Butler, 1882),, , holotype (NHMUK); $2-P$. ornatus, $\bigcirc^{7}$, holotype of Philanglaus penai Clench, 1957, Chile, Pichinahuel, 1100-1400 m, 23-31.I.1954, leg. L.Peña (CMNH); 3 - P. ornatus, O, Chile, Caramavida Araulo, 50 m, 13-14.I.1988, leg. J.Gonzales (MWM); $4-$ P. xylodopoecila (Zukowsky, 1954) comb.n., O’, neotype, Peru, Arequipa, 23.III.1936 (MHUB); 5 - P. xylodopoecila, O’, Chile, Prov. Tarapaca, Tarapaca, 25.I.1992 (MWM).

Рис. 1-5. Имаго Philanglaus: 1 - P. ornatus (Butler, 1882),, , голотип (NHMUK); 2 - P. ornatus, $0^{\top}$, голотип Philanglaus penai Clench, 1957, Chile, Pichinahuel, 1100-1400 m, 23-31.I.1954, leg. L.Peca (CMNH); 3 - P. ornatus, $\bigcirc^{7}$, Chile, Caramavida Araulo, $50 \mathrm{~m}$, 13-14.I.1988, leg. J.Gonzales (MWM); 4 - P. xylodopoecila (Zukowsky, 1954) comb.n., O, неотип, Peru, Arequipa, 23.III.1936 (MHUB); 5 - P. xylodopoecila, O', Chile, Prov. Tarapaca, Tarapaca, 25.I.1992 (MWM). 
harpe gradually narrowing from base to apex; juxta scaphoid with two robust sickle-curved lateral processes apically extended and bent; saccus robust, pyramidal; phallus thin, slightly shorter than valve, slightly curved, vesical aperture in dorso-apical position, vesical without cornuti.

DIAGNOSIS. The genus Philanglaus Butler, 1882 is morphologically close to the genera Hypopta Hübner, 1818 and Laberlia Yakovlev, Naydenov \& Penco, 2020 from which it differs in the bright contrast pattern of the fore wing, and the relatively smooth edged of the harpe. The apomorphies of the genus are the sickle-curved lateral processes of the juxta with expended curved apices.

COMPOSITION. Two species: Philanglaus ornatus Butler, 1882 and Philanglaus xylodopoecila (Zukowsky, 1954) comb.n.

DISTRIBUTION. Southern Peru and Chile.

Philanglaus ornatus Butler, 1882

Figs $1-3,6,8$.

Butler, 1882: 28-29 (in Hepialidae)

= Philanglaus penai Clench, 1957: 138-139.

MATERIAL EXAMINED: Chile: holotype (+) Philanglaus ornatus Butler, 1882 (Gen. slide № 124) (NHMUK); holotype $\sigma^{7}$ of Philanglaus penai Clench, 1957, Pichinahuel, 1100-1400 m, 2331.I.1954, leg. L. Peña (slide no. C-514, male genitalia; C. M. Ent. type series no. 327) $(\mathrm{CMNH})$; $10^{7}$, Caramavida Araulo, $50 \mathrm{~m}$, 13-14.I.1988, leg. J. Gonzales (Genitalpräparat Heterocera № 28.530) (MWM)

Reported by Gentili [1989]: 10², Arauco, Pichinahuel, $1100 \mathrm{~m}$ (Nahuelbuta W.) 23-31.I.1954, leg. L. Peña (MZUC); $10^{7}$, Loncotripan, Nahuelbuta, 27.I.1952, leg. G. Monsalve (MZUC); $20^{7} \sigma^{7}$, 19, Malleco, Termas de Río Blanco, 1200 m, 13-14.II.1964, leg. Wagenknecht (ANIC); 10 , 20.II.1955, leg. Wagenknecht (MNHC) $20^{7} \sigma^{7}$, 26.II.1962, leg. E. Krahmer (Prep. № PG-248, PG-279, PG287, PG-304, PG-315, PG-316, PG-333, PG-355) (IPCN).

DIAGNOSIS. The species differs from Ph. xylodopoecila in the thinner brown band on the fore wing postdiscally, and in the lanceolate, basally wide harpe, gradually narrowing to apex.

DISTRIBUTION. Chile (Santiago, Cachapoal, Arauco and Malleco Province). Gentili [1989] commented it can be found in forest mixt of Nothofagus Blume (Nothofagaceae) and Araucaria Juss. (Araucariaceae), between 1100 and 1400 meters above level sea, and between the $33^{\circ} 30^{\prime}$ and the $38^{\circ} 30^{\prime} \mathrm{S}$, by now only recorded in Chile.

NOTE. Zukowsky [1954] describes Langsdorfia xylodopoecila Zukowsky, 1954, externally similar to the previous species, from southern Peru (Arequipa Plateau). In the type series Zukowsky includes nine males, wherein the holotype and part of co-types were kept in the Zoological Museum of Hamburg, but in 1943 it was destroyed during the war. Thus, we have a clear evidence of the nomenclature type specimen loss [Weidner, 1974; Penco et al., 2020]. Examining the cotype (which we indicate as the neotype) deposited in MNKB and the supplementary materials from MWM, we established that this little known species also belongs to the genus Philanglaus.

\section{Philanglaus xylodopoecila (Zukowsky, 1954), comb.n. Figs 4-5, 7, 8 .}

Langsdorfia xylodopoecila Zukowsky, 1954: 92.

MATERIAL EXAMINED. Neotype (designated here, $0^{77}$ ), Peru, Yaucatal bei Ica, Arequipa, 23.III.1936 (Prep. N PG-837 P. Gentili) (MNKB). Chile: 10', Prov. Tarapaca, Tarapaca, 25.I.1992 (Genitalpräparat Heterocera № 28.515) (MWM).

DIAGNOSIS. The species differs from Philanglaus ornatus Butler, 1882 in the more developed brown pattern on the fore wing and in the very thin harpe.

DISTRIBUTION. Peru (Department of Arequipa) and Chile (Tarapacá Region)

Acknowledgments. Authors are grateful to Anna Ustjuzhanina (Tomsk) for the help in translation of the paper. The authors express their gratitude to Harald Sulak-Wildenauer (Munich) for providing the photos of the Cossidae type specimens from the USA museums. Authors are grateful to Dr. Wolfram Mey (Berlin), Dr. Jessica Bird (Washington), Mr. Geoff Martin and Alessandro Giusti (London), and Drs Martin Husemann and Reza Zahiri (Hamburg) for very important consultations. The authors are also indebted to deceased Prof. Thomas J. Witt (Munich) for the invaluable
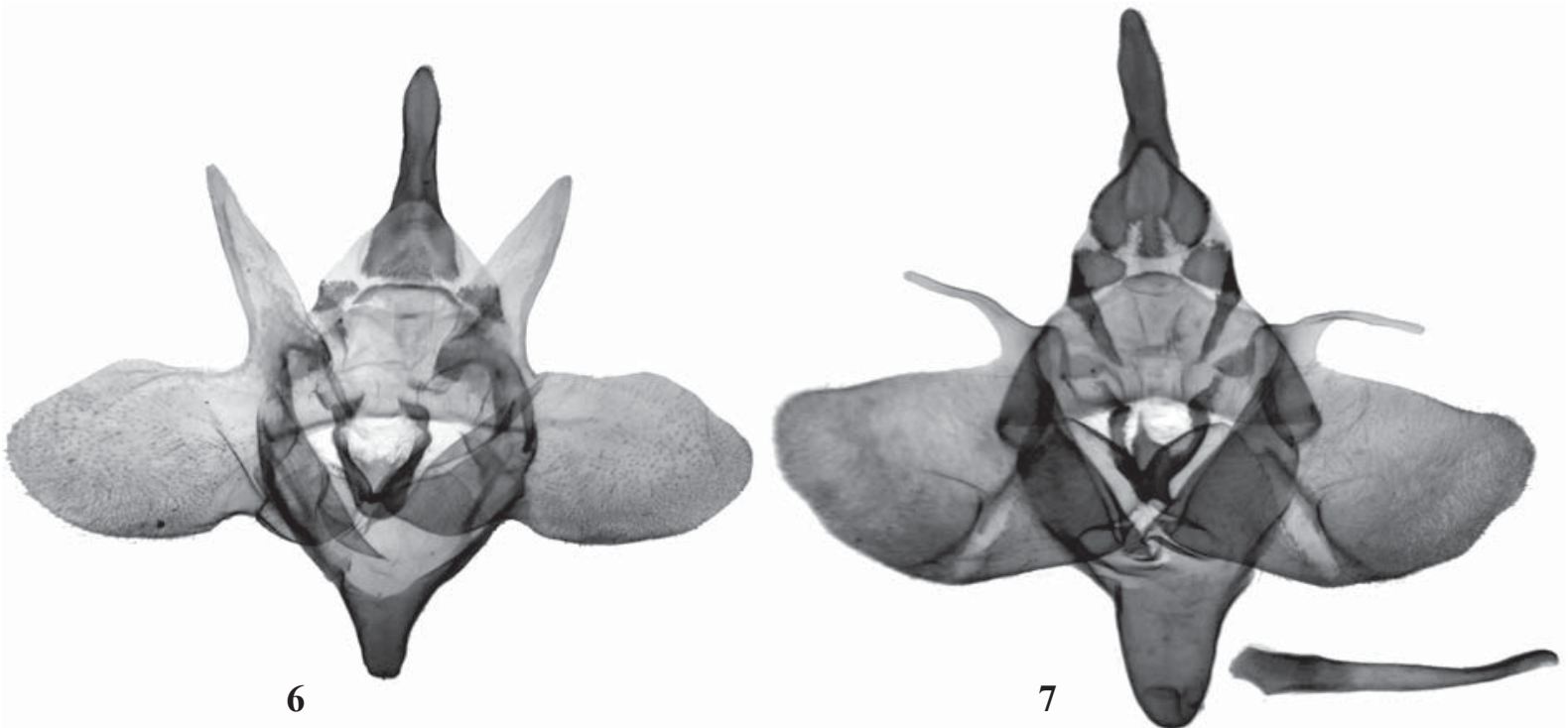

Figs 6-7. Male genitalia of Philanglaus: 6 - P. ornatus Chile, Caramavida Araulo (Genitalpräparat Heterocera № 28.530) (MWM); 7 - P. xylodopoecila, Chile, Prov. Tarapaca, (Genitalpräparat Heterocera № 28.515) (MWM).

Рис. 6-7. Гениталии самцов Philanglaus: 6 - P. ornatus Chile, Caramavida Araulo (Genitalpräparat Heterocera № 28.530) (MWM); 7 -. P. xylodopoecila, Chile, Prov. Tarapaca, (Genitalpräparat Heterocera № 28.515) (MWM). 
research assistance. Financial support for this study was provided by grants No. 18-04-00440 from the Russian Foundation for Basic Research.

\section{References}

Butler A.G. 1882. Heterocerous Lepidoptera collected in Chili by Thomas Edmonds, Esq. Part I. Sphinges and Bombyces // Transactions of the Entomological Society of London. Vol.1882. P.1-30.

Clench H.K. 1957. Cossidae from Chile (Lepidoptera) // Mitteilungen der Münchner Entomologischen Gesellschaft. Bd.47. S.122-142.

Dognin P. 1910. Hétérocères nouveaux de l'Amérique du Sud. Fascicule I. Rennes: Oberthür \& Fils. 46 p.

Dognin P. 1923. Hétérocères nouveaux de l'Amérique du Sud. Fascicule XXI. Rennes: Oberthür \& Fils. 38 p.

Donahue J.P. 1995. Cossidae // J.B. Heppner (ed.). Atlas of Neotropical Lepidoptera. Checklist: Part 2. Hyblaeoidea, Pyraloidea, Tortricoidea. Association for Tropical Lepidoptera. Gainesville. P.122-126.

Dyar H.G. 1940. Cossidae // A. Seitz (Hrsg.). Die Gross-schmetterlinge der Erde. Vol.6. Die amerikanischen Spinner und Schwarmer. Stuttgart: Alfred Kernen. S.1265-1285.

Gentili P. 1985. La familia Cossidae de Patagonia (Lep.: Ditrysia). (Thesis of) Facultad de Cs. Naturales y Museo-UNLP, Argentina.

Gentili P. 1989. Revision sistematica de los Cossidae (Lep.) de la Patagonia Andina // Revista de la Sociedad Entomológica Argentina. Vol.45. Nos1-4(86). P.3-75.

Lafontain J.D. 2004. Noctuoidea, Noctuidae (part), Noctuinae (part Agrotini) // R.W. Hodges (ed.). The Moths of America North of Mexico. Pt.27.1. Washington: The Wedge Entomological Research Foundation. 385 pp.

Naydenov A., Yakovlev R., Penco F., Sinyaev V. 2020. New data on Neotropical Carpenter-Moths of Subfamily Hypoptinae Neumoegen \& Dyar, 1894 (Lepidoptera: Cossidae). II. A review of the genus Dolecta Herrich-Schäffer, [1854], with description of seventeen new species // Ecologica Montenegrina. Vol.35. P.82-114. Doi: 10.37828/em.2020.35.7

Penco F.C., Yakovlev R.V., Naydenov A.E. 2019. New species of genus Breyeriana Orfila, 1957 (Lepidoptera: Cossidae: Hypoptinae) from Argentina // Ecologica Montenegrina. Vol.20. P.114-118.

Penco F.C., Yakovlev R.V., Naydenov A.E. 2020. A new monotypic genus of the subfamily Chilecomadiinae Dyar, 1940 (Lepidoptera: Cossidae) from South America // Ecologica Montenegrina. Vol.30. P.68-72. DOI: 10.37828/em.2020.30.5

Schaus W. 1905. Descriptions of new South American moths // Proceedings of the United States National Museum. Vol.29. No.1420. P.179-345.

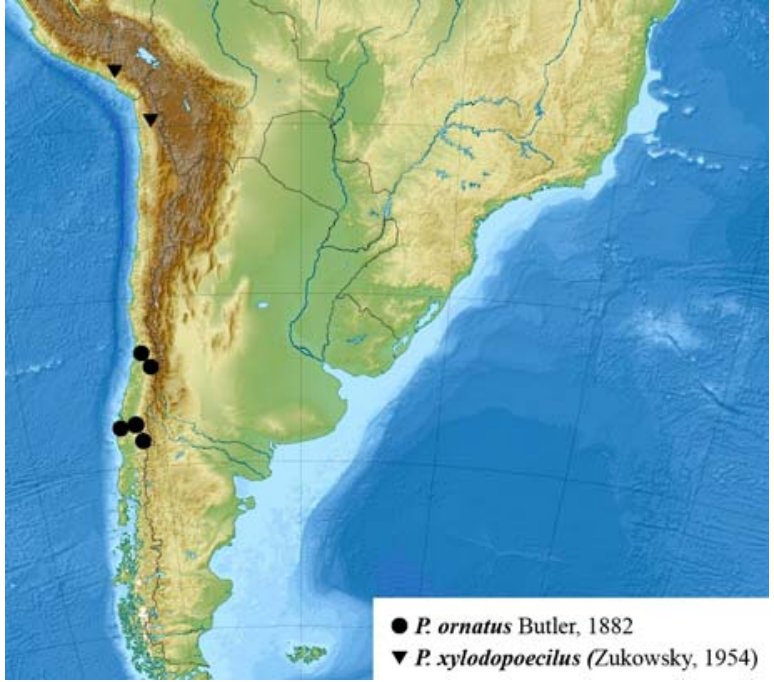

Fig. 8. Map of Philanglaus distribution.

Рис. 8. Карта распространения Philanglaus.

Schaus W. 1921. New species of Lepidoptera in the United States National Museum // Proceedings of the United States National Museum. Vol.59. No.2372. P.349-396.

Ureta E. 1957. Revision de la familia Cossidae (Lep. Het.) en Chile // Boletín del Museo Nacional de Historia Natural. Vol.27. No.2. P.129-153.

Schoorl J. W. 1990. A phylogenetic study on Cossidae (Lepidoptera: Ditrysia) based on external adult morphology // Zoologische Verhandelingen. Vol.263. P.4295.

Yakovlev R.V., Naydenov A.E., Penco F.C. 2019. New data on Neotropical Carpenter-Moths of Subfamily Hypoptinae Neumoegen \& Dyar, 1894 (Lepidoptera: Cossidae). I. New taxa with bifurcated uncus // Ecologica Montenegrina. Vol.26. P.4-13.

Weidner H. 1974. Die Entomologischen Sammlungen des Zoologischen Instituts und Zoologischen Museums der Universität Hamburg. XI Teil 1. Insecta VIII // Mitteilungen aus dem Hamburgischen Zoologischen Museum und Institut. Bd.70. S.181-266.

Zukowsky B. 1954. Cossidae // E. Titschack (Hrsg.) Beiträge zur Fauna Perus. Nach der Ausbeute der Hamburger SüdperuExpedition 1936, anderer Sammlungen, wie auch auf Grund von Literaturangaben. Bd.4. Wissenschaftliche Bearbeitungen. Jena: VEB Gustav Fischer Verlag. S.87-92. 